\title{
How Does a U.S. Geological Survey Streamgage Work?
}

Information on the flow of rivers and streams is a vital national asset that safeguards lives, protects property, and ensures adequate water supplies for the future. The U.S. Geological Survey (USGS) operates a network of more than 9,000 streamgages nationwide with more than 500 in Texas.

If you have ever crossed a highway bridge and noticed a metal structure with an antenna by the side of it, you've probably seen a USGS streamgage (fig. 1). A streamgage contains instruments that measure and record the amount of water flowing in the river or stream, or its discharge. Generally, these measurements occur automatically every 15 minutes or more frequently in times of flooding.

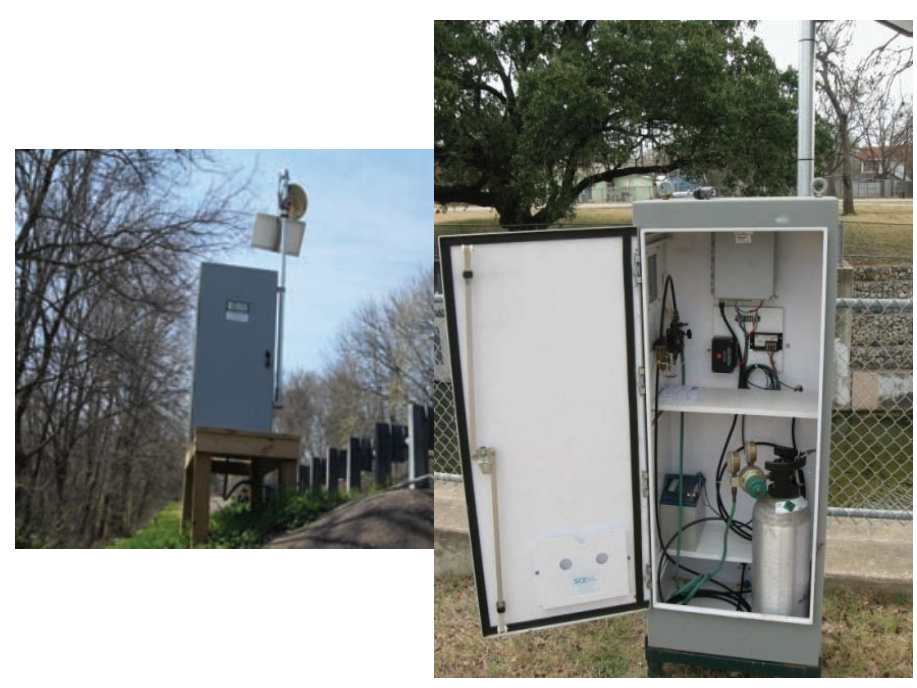

Figure 1. Examples of gage structures located at U.S. Geological Survey streamgaging stations.

USGS computers convert the water-level data into information about the flow of the river. The flow and gage-height data are then made available to users over the Internet at $h t t p: / /$ water. usgs.gov/nwis/.

\section{How Streamflow Is Measured}

Measuring streamflow in rivers or streams is similar to taking the pulse of blood flow in a human body. It is important to measure streamflow so that scientists and water managers can make informed decisions about a river's or stream's health.

Measuring streamflow generally involves several steps. These include recording continuous water levels, taking discharge measurements in the river or stream, developing a mathematical relation between stage and discharge, and then applying this relation to the continuous stage record to compute streamflow. Because it is not practical for a streamgage to

\author{
Words that have the same meaning used throughout this text: \\ Stream stage $=$ gage height $=$ water level \\ Streamflow $=$ discharge $=$ flow \\ Streamflow station $=$ streamgage $=$ gaging station $=$ gage
}

continuously measure streamflow, the gage height of a stream is continuously measured. There is a strong mathematical relation between this height and streamflow and, as a result, a continuous record of streamflow can be calculated from the record of stream stage.

Measuring the relative height of streams is done many times a day through an underwater tube contained in the streamgage (fig. 2). Gas is continually pushed through the tube into the stream. As the depth of water above the tube opening increases, more pressure is required to push the gas through the tube. As the water decreases, less pressure is needed to push the gas out. This level of pressure is used to calculate the height of the water above the tube. These changes in pressure are recorded as changes in height, or stage. Stage data are measured usually every 15 minutes. When intense rainfall and runoff cause the river or stream to rise quickly, the time intervals sometimes are shorter. The time interval can be as short as every 5 minutes. These data are transmitted to a satellite on a preset schedule which is usually every 1 to 4 hours. During high water or other emergency situations, data will be sent to the satellite every 15 minutes to provide more timely data.

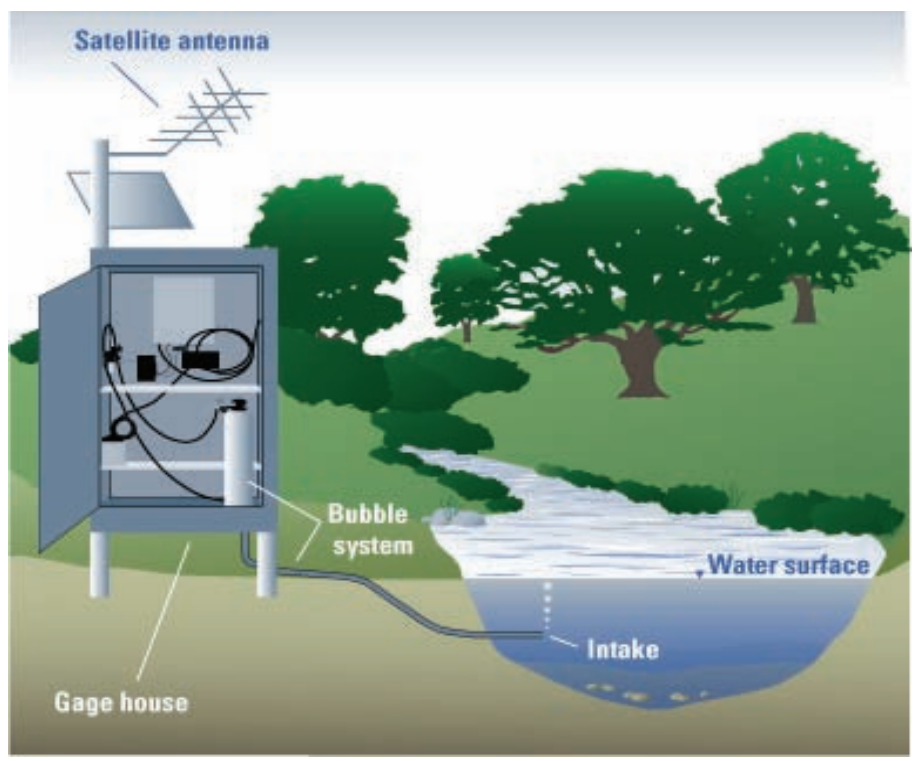

Figure 2. Diagram of a typical streamgage installation with equipment used to measure stream stage (by L.S. Coplin, U.S. Geological Survey). 


\section{The Relation of Height to Streamflow}

The continuous record of stage is converted to streamflow by applying a mathematical rating curve. A rating curve (fig. 3) is a graphic representation of the relation between stage and streamflow for a given river or stream. USGS computers use these site-specific rating curves to convert the water-level data into information about the flow of the river.

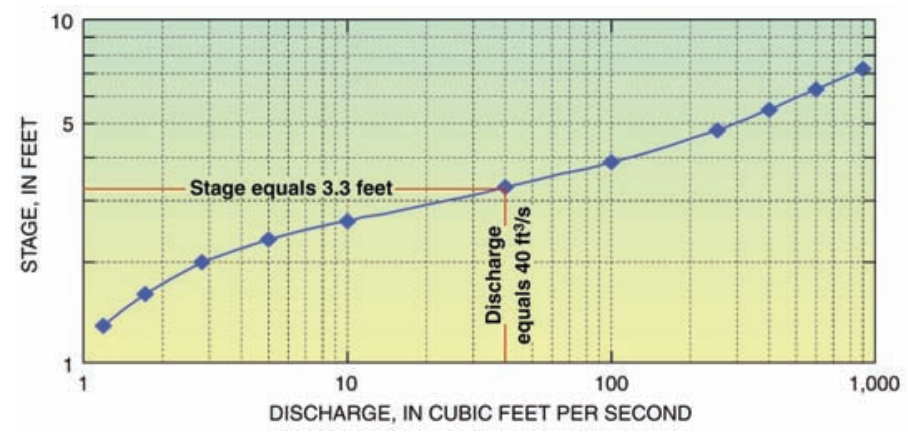

Figure 3. Example of a typical stage-discharge relation or rating curve (Nielsen and Norris, 2007, fig. 2).

The rating curve is developed from a number of physical discharge measurements collected over a period of time and over a range of stages (from low flow to flood stage). Each point on the graph represents one discharge measurement.

Streamflow is measured in cubic feet per second, which is equivalent to a box of water measuring 1 by 1 foot with a flow rate of about 7.5 gallons per second. The stage-discharge relation depends on the shape, size, slope, and roughness of the channel at each gage and is different for every streamgage. A rating curve often changes after a flood when the physical force of high water movement can change the dimensions of the streambed or stream channel. To keep the rating curve accurate and up-to-date, USGS hydrologic technicians visit each streamgage about once every 6 weeks to measure the flow directly and also measure high flows when they happen.

\section{Making Discharge Measurements}

In general, river discharge is computed by multiplying the area of water in a channel cross section (fig. 4) by the average speed, or velocity of the water in that cross section:

\section{Discharge $=$ Area $\times$ Velocity}

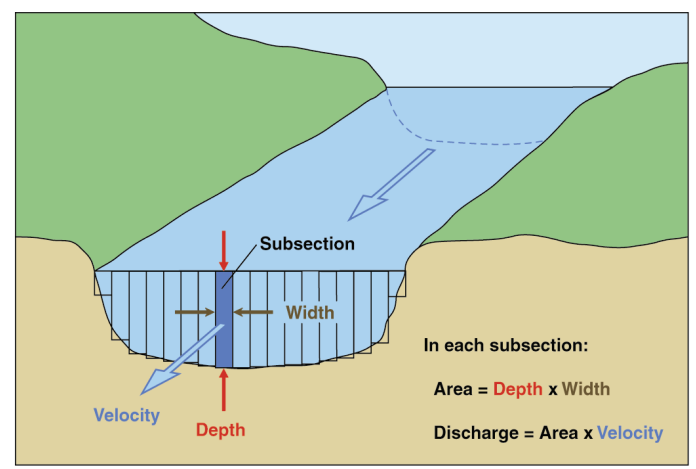

Figure 4. Diagram of a channel cross section with subsections (Olson and Norris, 2007, fig. 3).

\footnotetext{
Publishing support provided by

Lafayette Publishing Service Center
}

The most common method used by the USGS for measuring velocity is with a current meter. However, a variety of advanced equipment can also be used to sense stage and measure streamflow. In the simplest method, a current meter turns with the flow of the river or stream. The current meter is used to measure water velocity at predetermined points (subsections) along a marked line, suspended cableway, or bridge across a river or stream. The depth of the water is also measured at each point. These velocity and depth measurements are used to compute the total volume of water flowing past the line during a specific interval of time. Usually a river or stream will be measured at 25 to 30 regularly spaced locations across the river or stream.

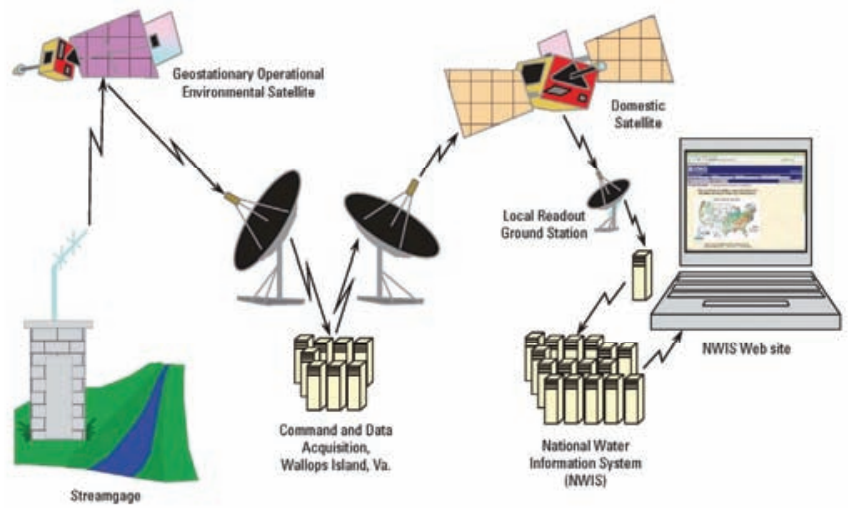

Figure 5. Diagram of how streamflow data are transferred from streamgage to the Internet (Sauer and Turnipseed, 2010, fig. 48).

\section{Streamflow Data on the Internet}

All USGS stage and streamflow information is available in near real time through the National Water Information System Web Interface (NWISWeb) for Texas (fig. 5) at: http://waterdata.usgs.gov/tx/nwis/rt). In addition to real-time streamgage data, NWISWeb also provides access to daily discharges and annual maximum discharges for the period of record for all active and discontinued streamgages operated by the USGS.

This information is used by the National Weather Service to forecast flooding and by emergency managers to make informed decisions to protect public safety in times of flooding.

\section{References}

Nielsen, J.P., and Norris, J.M., 2007, From the river to you-USGS real-time streamflow information: U.S. Geological Survey Fact Sheet 2007-3043, 4 p. (Also available at http://pubs.usgs.gov/ $f_{s} / 2007 / 3043 /$.)

Olson, S.A., and Norris, J.M., 2007, U.S. Geological Survey streamgaging...from the National Streamflow Information Program: U.S. Geological Survey Fact Sheet 2005-3131, 4 p. (Also available at http://pubs.usgs.gov/fs/2005/3131/.)

Sauer, V.B., and Turnipseed, D.P., 2010, Stage measurement at gaging stations: U.S. Geological Survey Techniques and Methods, book 3, chap. A7, 45 p. (Also available at http://pubs.usgs.gov/tm/tm3-a7/.)

-Dee L. Lurry

\section{For additional information, contact}

Director, USGS Texas Water Science Center

World Wide Web: http://tx.usgs.gov/

E-mail: gs-w-txpublic-info@usgs.gov 